\title{
ERRATA
}

The correct title of the paper by B. CARMON and A. DYER (published in J. Radioanal. Nucl. Chem., Articles, Vol. 109, 1987, No. 1, pp. 229-236) is as follows:

\section{CERENKOV SPECTROSCOPIC ASSAY OF THE FISSION ISOTOPES}

II. ASSAY OF ${ }^{106}$ Ru IN UV-COLOUR-QUENCHED SOLUTIONS ON PRESENCE OF OTHER BETA-EMITTERS

Figure 2 to the paper by E. J. UWAH and D. E. AJAKAIYE (published in J. Radioan: Nucl. Chem., Articles, Vol. 100, 1986, No. 1, pp. 177-184) is as follows:

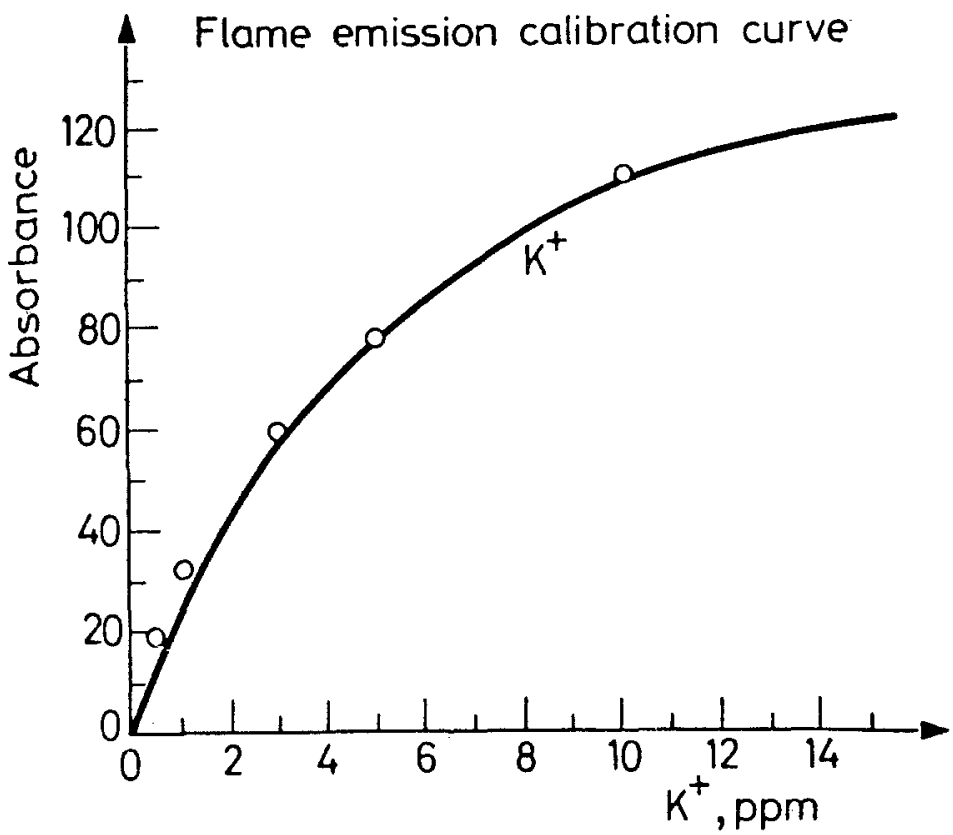

